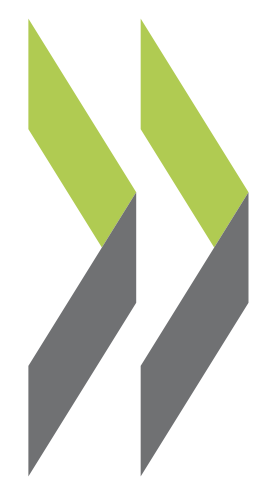

OECD Working Papers on Insurance and Private Pensions No. 25

\title{
Policy Options for the Payout Phase
}

\section{Pablo Antolín}




\section{\ęC}

POLICY OPTIONS FOR THE PAYOUT PHASE

Pablo Antolin

September 2008

\section{OECD WORKING PAPER ON INSURANCE AND PRIVATE PENSIONS}

No. 25

Financial Affairs Division, Directorate for Financial and Enterprise Affairs

Organisation for Economic Co-operation and Development

2 Rue André Pascal, Paris 75116, France

www.oecd.org/daf/fin/wp 


\begin{abstract}
RÉSUMÉ
Policy option for the payout phase

This paper assesses how countries' pension arrangements and regulation shape the appropriate structure and flexibility of retirement payout options. The paper aims at providing a guide to policy makers on how to address the diverse questions posed when designing the payout phase or promoting DC pension arrangements, as well as encouraging a market for annuities. The paper addresses questions concerning the type of retirement payout options for accumulated assets in DC plans a country should allow, which entities should provide annuities, and the type of annuity products that could be allowed. The main recommendation is for policy makers to consider mandating deferred life annuities that start paying at very old ages (e.g. at age 85) and allow for the remaining assets accumulated in DC accounts to be allocated as programmed withdrawals (preferably with flexibility to face contingencies).
\end{abstract}

JEL codes: D11, D14, D91, E21, G11, G38, J14, J26

Keywords: Annuities, programmed withdrawal, lump-sums, retirement income, annuity providers, insurance companies, annuity markets, longevity risk, and deferred life annuities.

$* * * * *$

\title{
Options s'offrant aux pouvoirs publics pour la phase de versement des pensions
}

Ce document examine comment les dispositions et réglementations prises par les pays en matière de pensions influent sur la structure et la flexibilité des options qui s'offrent en phase de versement, une fois la retraite venue. Il vise à servir de guide pour les responsables publics en leur montrant comment aborder les diverses questions qui se posent au moment de fixer les modalités de la phase de versement, ou pour promouvoir des dispositifs de pension à cotisations définies, et aussi encourager un marché de rentes. Le document examine les options qui peuvent s'envisager en phase de versement des avoirs accumulés sur les plans à cotisations définies, quelles entités devraient être habilitées à servir des rentes et le type de produits de rente qui peut être autorisé. La principale recommandation à l'intention des responsables publics est d'imposer des rentes viagères différées qui ne commenceront d'être servies qu'à un âge très avancé (par exemple à partir de 85 ans) et de prévoir que le solde des actifs accumulés sur les comptes à cotisations définies pourra être perçu sous la forme de retraits programmés (de préférence avec une marge de flexibilité pour faire face à des imprévus).

JEL codes: D11, D14, D91, E21, G11, G38, J14, J26

Mots clés: rentes viagère, retrait programme, versement unique, revenue des retraites, pourvoyeurs des rentes viagères, compagnie d'assurances, marche des rentes viagères, risque de longévité, et rentes viagères diffères.

\section{Copyright OECD, 2008}

Applications for permission to reproduce or translate all, or part of, this material should be made to: Head of Publications Service, OECD, 2 rue André-Pascal, 75775 Paris Cédex 16, France. 
POLICY OPTIONS FOR THE PAYOUT PHASE

TABLE OF CONTENTS

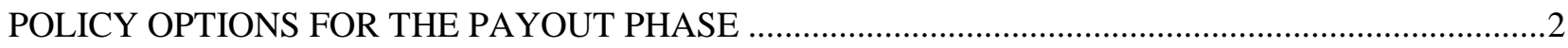

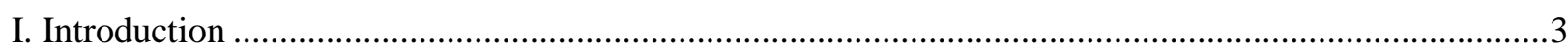

II. What type of retirement payout options for accumulated assets in DC plans should a country allow?..4

II.1. What are the main options available for the payout phase?.......................................................

II.2. How does the country context affect the choice of retirement payout options? ...............................5

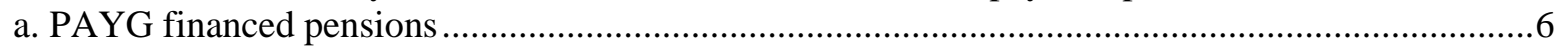

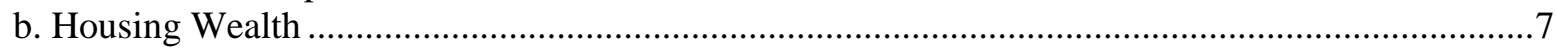

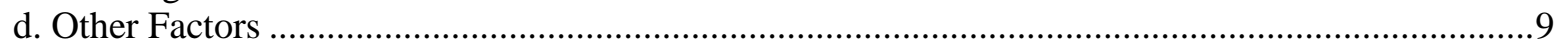

II.3. How does the market context affect the choice of retirement payout options? ..............................10

a. The level of development of insurance markets ...........................................................................10

b. What are the main constraints facing annuity markets? ...............................................................11

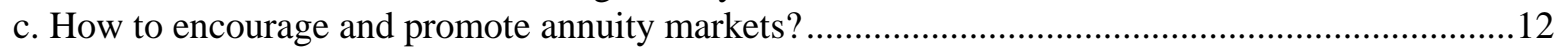

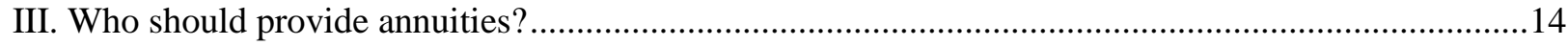

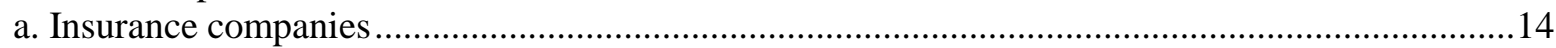

b. How to disseminate information as regards annuity providers? ..............................................15

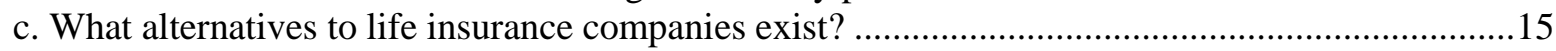

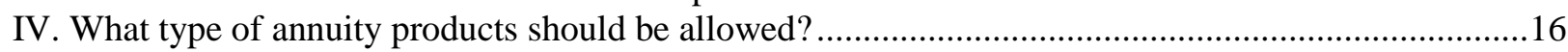

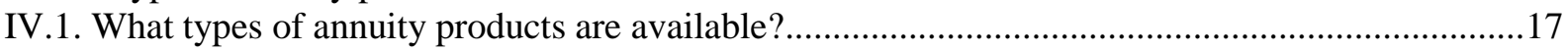

IV.2. How to protect against the risk associated with buying an annuity? ?........................................19

a. Which approaches exist for facing the risk associated with the time of annuitization?..................20

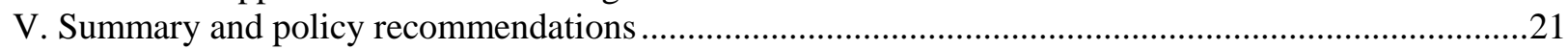

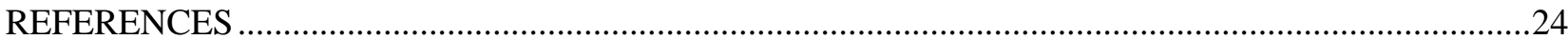

\section{Boxes}

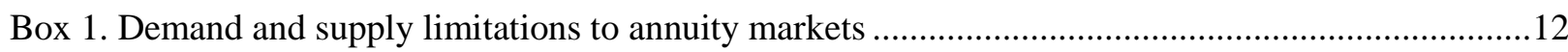

Box 2. Classifying different type of annuity products .........................................................................17 


\title{
POLICY OPTIONS FOR THE PAYOUT PHASE
}

\author{
by Pablo Antolin ${ }^{1}$
}

\section{Introduction}

The international pension environment is shifting from defined benefit arrangements (either PAYGfinanced or funded) - in which the amount of retirement benefits is determined largely by years of service - to defined contribution (DC) arrangements, whereby retirement wealth depends on how much workers save and how successfully they allocate their assets accumulated in DC plans. The efficient allocation of these assets requires the managing of risks, such as the timing of annuitization and longevity risk (i.e. the possibility of outliving one's retirement income). It also depends on the type of options and products available, and, crucially, on the regulatory environment.

The main purpose of this paper is to assess how countries' pension arrangements and regulation (i.e. the country context) shape the appropriate structure and flexibility of retirement payout options. The paper aims at providing a guide to policy makers on how to address the diverse questions posed when designing the payout phase or promoting DC pension arrangements, as well as encouraging a market for annuities.

The design of the payout phase and the different retirement options are now taking priority in pension discussions, in particular as many countries that introduced an accumulation phase based on DC pension arrangements will shortly have to start paying out pensions (e.g. Latin American and Central and Eastern European countries). In addition, other countries have been shifting to DC pension plans and may need to promote or encourage certain retirement payout options in order to guarantee that people will have appropriate retirement income and longevity protection. The driving objective of any pension system should be to ensure that individuals' retirement savings - i.e. the assets accumulated in DC pensions - are protected and will not run out at old-age. However, there needs to be a balance, with the guarantees provided to retirees not so burdensome to the providers of payout options (e.g. annuity providers) that they become unable or unwilling to supply the necessary products.

The paper is organised in three main parts. After reviewing the main retirement payout options, the report discusses how the country and the market context should determine the form of the retirement options that should be allowed. The main driving argument of the paper is that the choice of payout options allowed should be consistent with the goal of the overall pension system, while at the same time balancing the existing trade-offs. The paper also discusses the practical problems faced by policy makers in promoting annuitization in the light of limited annuity markets.

The second part of the paper focuses on the regulatory framework, in particular examining which entities should be the providers of annuity products. The argument is made that countries should consider allowing as many providers as possible in order to promote competition, lower prices and lower costs. However, providers either should be limited to entities that are subject to explicit capital adequacy

\footnotetext{
${ }^{1}$ The author is principal economist of the private pension unit at the OECD. He would like to thanks delegates to the OECD Working Party on Private Pensions; André Laboul, Clara Severinson and Juan Yermo from the OECD for their comments and suggestions, as well as Colin Pugh and Rob Rusconi for helpful conversations. This paper would not have been possible without the inestimable contributions of Fiona Stewart. This work has benefit from financial contributions from Generali and BBVA. The views expressed are the sole responsibility of the author and do not necessarily reflect those of the OECD or its member countries. The author is solely responsible for any errors.
} 
requirements or there should be mutual, risk-sharing arrangements in place. The paper also examines different approaches to disseminate information and promote competition in life annuity markets.

The final issue addressed is the different type of annuity products and the type of guarantees involved, as well as on the risks associated with the timing of annuitization.

The paper concludes that in designing the payout phase for assets that have accumulated in DC pension plans, policy makers need to consider carefully the choices allowed at retirement to ensure consistency with the overall pension arrangements. In this regard, countries where much of the retirement income is already annuitized through PAYG-financed public pensions, DB pensions or other sources of wealth can allow more choice of payout options as well as a wider variety of annuity products (provided that individuals have an adequate absolute level of income). However, countries where most retirement income comes from assets accumulated in DC pensions may need to be more restrictive in the choices provided, as well as on the type of annuity products allowed, making sure that a large share of those assets are used to buy annuities that fully protect retirees from longevity risk. The paper also suggests that regulation is probably the best approach to deal with the problems with annuity markets. In the context of which entities should provide annuities, the paper indicates that the main arguments should be to promote competition, information disclosure and a sound prudential framework. Finally, the discussion of annuity products and risks suggests that deferred life annuities are one product that seems to address, at least partially, some of the main risks.

\section{What type of retirement payout options for accumulated assets in DC plans should a country allow?}

This section reviews the main retirement payout options available for the payout phase (building on the companion paper by Antolin et al., 2008), and discusses the need to carefully consider the specific country and market contexts when deciding which options to allow. This decision requires balancing the trade-off between flexibility and protection, and ensuring consistency with the overall goals of the pension system.

\section{II.1. What are the main options available for the payout phase?}

There are three main options available for the payout phase in order to allocate the assets accumulated in DC pension plans: lump-sum payments, programmed withdrawals, and annuities (table 1). ${ }^{2}$ It is also possible to have combined arrangements that may involve any combination of these three.

Table 1. Main retirement payout options and features

\begin{tabular}{lccc} 
& \multicolumn{3}{c}{\begin{tabular}{c} 
Provide \\
\cline { 2 - 4 }
\end{tabular}} \\
& $\begin{array}{c}\text { Protection } \\
\text { against } \\
\text { Flexibility } \\
\text { liquidity }\end{array}$ & $\begin{array}{c}\text { longevity } \\
\text { risk }\end{array}$ & Bequest \\
\cline { 2 - 4 } Lump-sum & Yes & No & Yes \\
Programmed withdrawal & Yes & No & Yes \\
Life annuities & No & Yes & No \\
\hline
\end{tabular}

\footnotetext{
${ }^{2}$ Programmed withdrawals are also called phased withdrawals or allocated pensions (e.g. in Australia).
} 
With lump-sums, individuals receive the entire value of the assets accumulated for retirement as a single payment, that can be freely used, for example, to invest, buy an annuity, pay down debt, cover for contingencies (e.g. health care expenses), or spend freely on discretionary items such as holidays. Under programmed withdrawals, individuals agree on a schedule of periodic fixed or variable payments. These payments can be determined by dividing the accumulated capital in various ways, for example, by a fixed number of years ${ }^{3}$ or by the expected life expectancy in each period. The schedule of payments also can be such that payments are front-loaded, and they can also incorporate flexibility, for example, adjusting payments in case health care contingencies arise. A life annuity, on the other hand, is a stream of income paid at some regular interval for as long as the individual lives.

The main factors that differentiate between these options are the degree of flexibility versus the degree of protection from longevity risk. Lump-sum payments are fully flexible and provide complete liquidity, allowing people to dispose of and allocate their funds as they wish (e.g. to pay down debt, to cover health care expenses, etc.). Lump-sums also permit individuals to leave bequests. However, individuals opting for lump-sums require strong financial discipline to manage their resources efficiently, as lump-sums fail to provide protection from outliving one's own resources -- i.e. the individual bears all the so called longevity risk. In this regard, programmed withdrawals provide more financial discipline than lump-sums while maintaining some flexibility, access to liquidity and the possibility of leaving bequests. Unfortunately, they also fail to provide any protection from longevity risk.

Life annuities by contrast, fully protect individuals from longevity risk, but at least in their 'plain vanilla' form, are inflexible and illiquid, and do not allow for bequests. Nevertheless, more complex annuity products are available, which are designed to satisfy the need for flexibility and, in particular, the bequest motive (see discussion below).

Combining different arrangements may achieve both goals of flexibility and protection from longevity risk. For example, combining programmed withdrawals with a deferred life annuity bought at retirement that begins paying out at a later age (e.g. at age 85) may allow annuitants to enjoy the higher flexibility and liquidity of programmed withdrawals, whilst at the same time the deferred life annuity protects them from longevity risk. ${ }^{4}$ Moreover, calculations show that such combinations can be highly cost effective, with only around $10-15 \%$ of assets on hand at retirement needed to buy such an annuity.

\section{II.2. How does the country context affect the choice of retirement payout options?}

The decision as to which of these retirement payout options policy makers should allow may be country specific as the type of pension arrangements in place, the availability of other sources of wealth available to tap into in retirement, and government priorities as regard pensions may affect the possible choices.

\footnotetext{
${ }^{3}$ This is equivalent to an annuity certain or fixed-term annuity (see Box 2 below).

4 Throughout this paper, deferred annuities refer to deferred products which commence payment of a stream of income from a specified future date until death - i.e. they provide longevity insurance. Some other papers distinguish between deferred annuities - which are instruments that refund the entire cash value in the event of death before the payout of the income stream has commenced - and longevity insurance, under which payments only occur in the event of survival until the specified date (i.e. there is no refund of the capital should the annuitant die before the deferred annuity payment date is reached). The distinction based on capital refunds is not discussed in this paper.
} 


\section{a. PAYG financed pensions}

Considering that one of the main objectives of pension provision is to protect people from outliving their own resources -- that is, to insure them against longevity risk -- the share of retirement income from assets accumulated in DC plans that people may need to annuitize would depend on the amount of retirement income already annuitized through PAYG-financed pensions. ${ }^{5}$ Countries where a significant share of retirement income already comes in the form of annuity payments from PAYG-financed pensions should be able to allow more flexibility and choice in the forms of retirement payout options that are provided for DC plans. Figure 1 shows that some countries do indeed have PAYG-financed public pensions guaranteeing a significant replacement rate in the form of annuity payments. Those countries may not need to encourage full annuitization of assets accumulated in DC plans, and may wish to allow more flexibility and choice in the allocation of these assets. However, it should be noted that this analysis considers only average incomes. The range of replacement rate may differ widely between individuals, and policymakers may therefore need to design the payout system more subtly, taking different income groups into account as a 'one size fits all' policy may not be appropriate. The analysis also considers replacement rates as a percentage of average income. Clearly policy makers will also need to consider absolute income levels, with flexibility in withdrawals maybe not appropriate for those receiving only low absolutely sums, whilst placing unnecessary restrictions on those with high income levels seems unnecessary.

Figure 1. Gross replacement rates in PAYG-financed pensions ${ }^{1}$

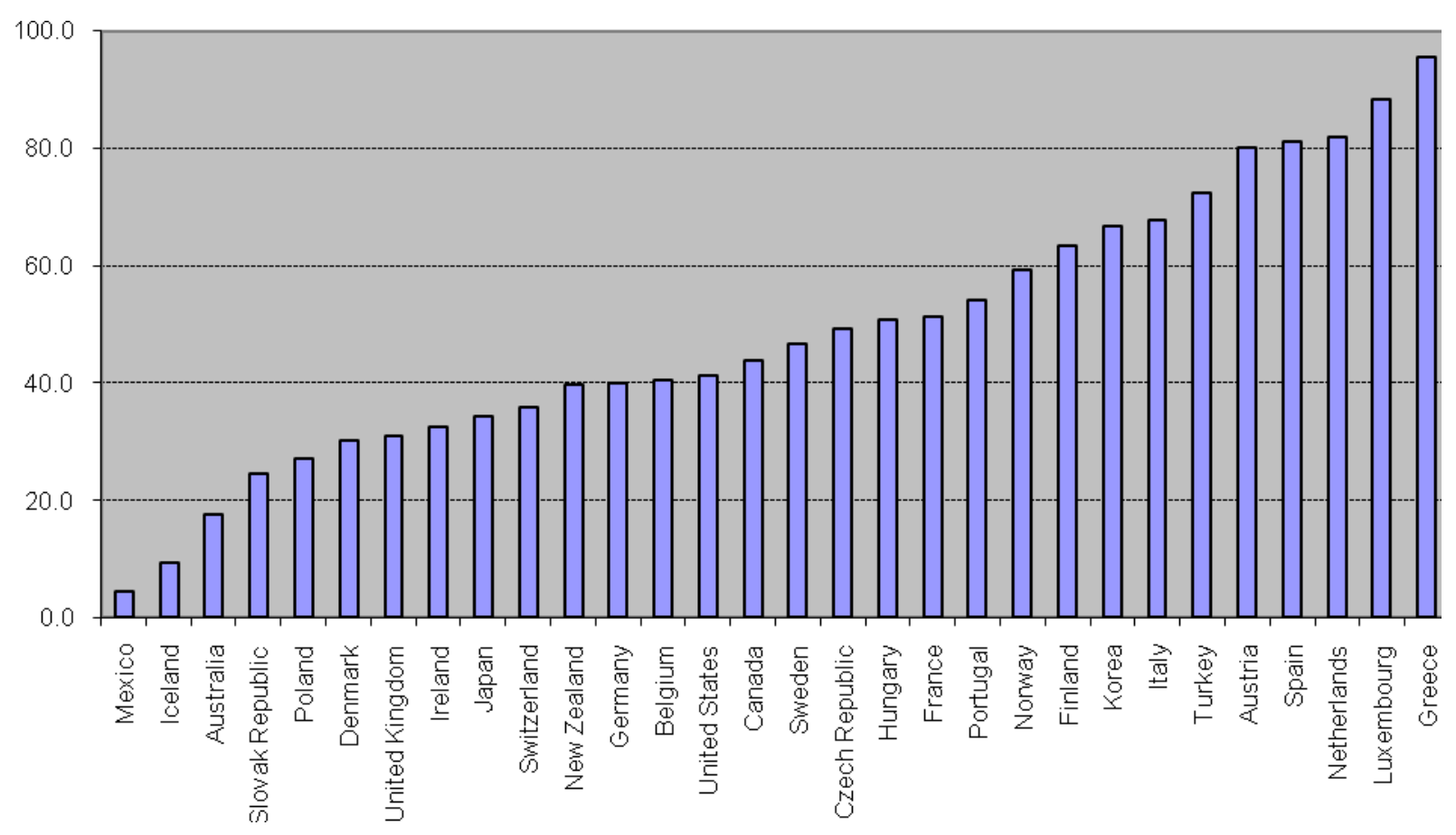

Source: OECD (2007).

1. Replacement rates are calculated for people with average income. The replacement rate of the Netherlands includes the mandatory DB plans.

\footnotetext{
${ }^{5}$ Ideally, the analysis should focus on the total amount of retirement income already annuitized through PAYGfinanced and occupational DB pensions. Unfortunately, data on the amount of retirement income annuitized through voluntary occupational DB pensions is hard to come by. In the case of the Netherlands, the data correspond to sum of the PAYG-financed and the mandatory DB pensions.
} 
However, in practice there is only weak empirical evidence that countries with large PAYG-financed pensions do indeed allow more flexible retirement payout options. Figure 2 plots an index of flexibility of retirement payout options allowed for DC plans in each country against the replacement rate provided by PAYG-financed pensions. ${ }^{6}$ Using a multinomial logistic regression to estimate their correlation suggest that it is not statistically significant. ${ }^{7}$ Moreover, the pseudo- $\mathrm{R}^{2}$ statistic indicates that the linear correlation fit fails to explain most of the variation. Therefore, a statistically distinctive correlation between the share of previous wages covered by pension payment from PAYG-financed plans and the different degree of flexibility of retirement payout options allowed in each country cannot be found. For example, some countries that are close to the OECD average replacement rate of 58\% allow only limited flexibility (such as Hungary, Bulgaria, France and Thailand), whilst others (e.g. Belgium, Czech Republic, and Portugal) allow far more choice.

Figure 2. Relationship between PAYG-financed pensions and flexibility retirement payout options allowed

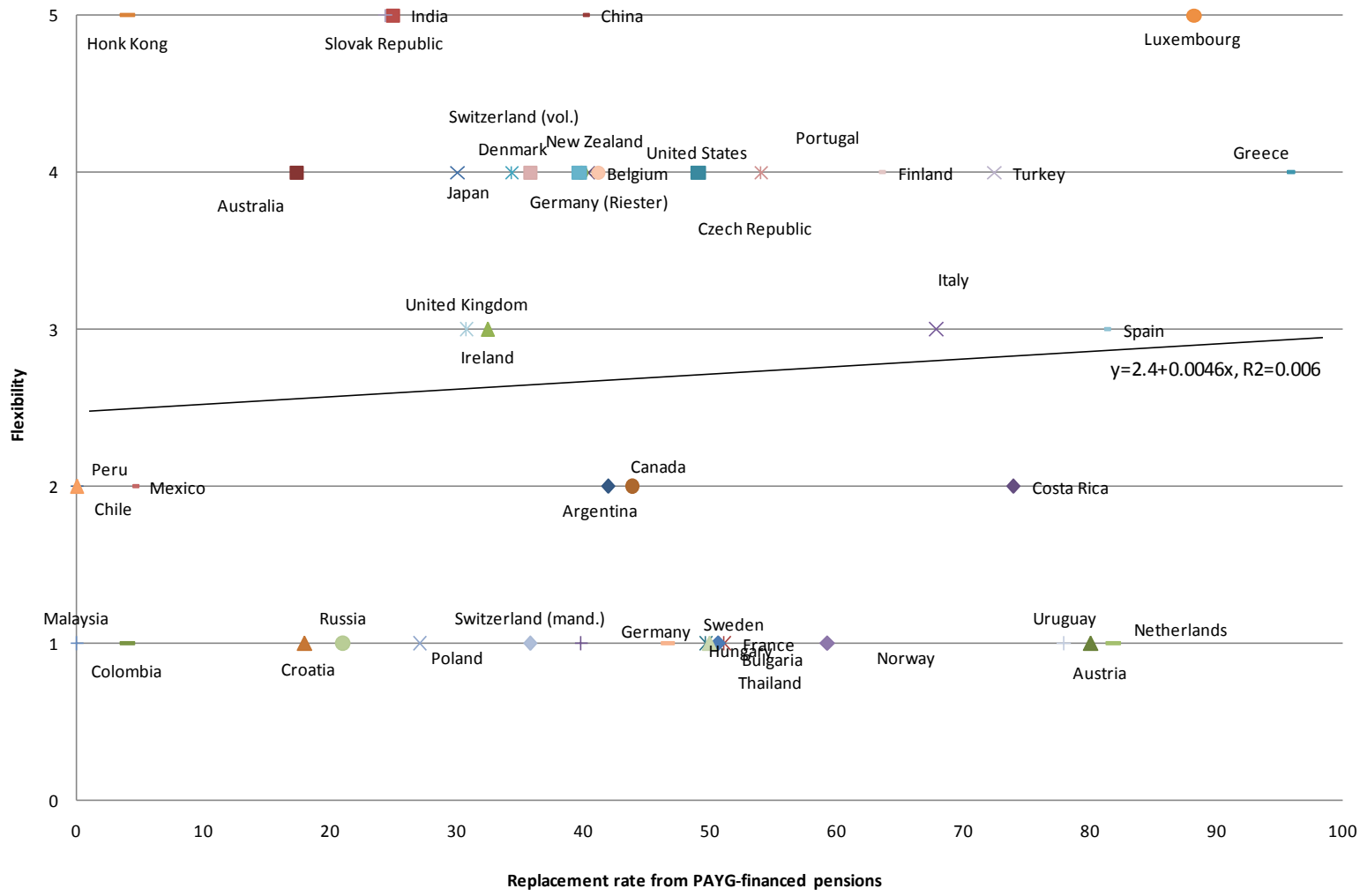

Source: Replacement rates for OECD countries come from OECD (2007), for Latin American countries from Whitehouse (2007), and for Asia from OECD (2008b). The information to construct the index on flexibility comes from Antolin at al. (2008). It assumes a value of 1 to 5 depending on whether the payout options allowed are just life annuities; life annuity or programmed withdrawals; lump-sum plus life annuity, lump-sum or life annuity; or lumps-sum, respectively.

\section{b. Housing Wealth}

If the size of the PAYG-financed public pension does not explain the flexibility of regulation in the payout phase, it is fair to ask whether other explanatory factors can be found. For example, as with large,

\footnotetext{
${ }^{6}$ Flexibility is measured from 1 to 5 according to the following ascending order: life annuities only, life annuity or programmed withdrawal, lump-sums plus life annuity, lump-sum or life annuity, lump-sum.

${ }^{7}$ The appropriate statistical approach to estimate the correlation between a discrete (flexibility) and a continuous variable (replacement rate) is a multinomial logistic regression.
} 
guaranteed, public pensions, if individuals have access to other sources of wealth in retirement, it should again be possible to allow them greater flexibility in deciding how to draw down the assets accumulated in their DC pension plans. Housing is a good approximation for retirement wealth, being by far the largest assets for most individuals in OECD countries. Individuals could tap into their housing wealth in order to finance retirement using, for example, reverse mortgages. ${ }^{8}$ Therefore, in countries like Australia that have a relatively high housing ownership ratio, allowing retirees more flexibility and choice of retirement payout options would seem appropriate. Switzerland, on the other hand, has a relatively low housing ownership ratio which would logically lead to restrictions on the payout options available from pension plans, as other assets may not be available to provide a steady income in retirement should these assets run out.

Unfortunately, the empirical evidence is again weak. Figure 3 plots the same index of flexibility of choice as above against the share of owner-occupied housing (housing ownership rate). The multinomial logit estimation of the correlation between the degree of flexibility and the rate of housing ownership show a lack of a statistically significant relationship. Even when PAYG-financed replacement rates and housing ownership are combined, no significant correlation with the flexibility of the pension pay-out phase regulation can be found. Contrast, for example, countries that have a share of owner-occupied housing in the average range of 50-70\%. Among these countries, the Netherlands, France, Austria and Sweden still have limited flexibility in retirement payout options, while countries such as Denmark, Japan, New Zealand and Portugal allow individuals far more choice.

Figure 3. Relationship between housing ownership and flexibility of retirement payout options

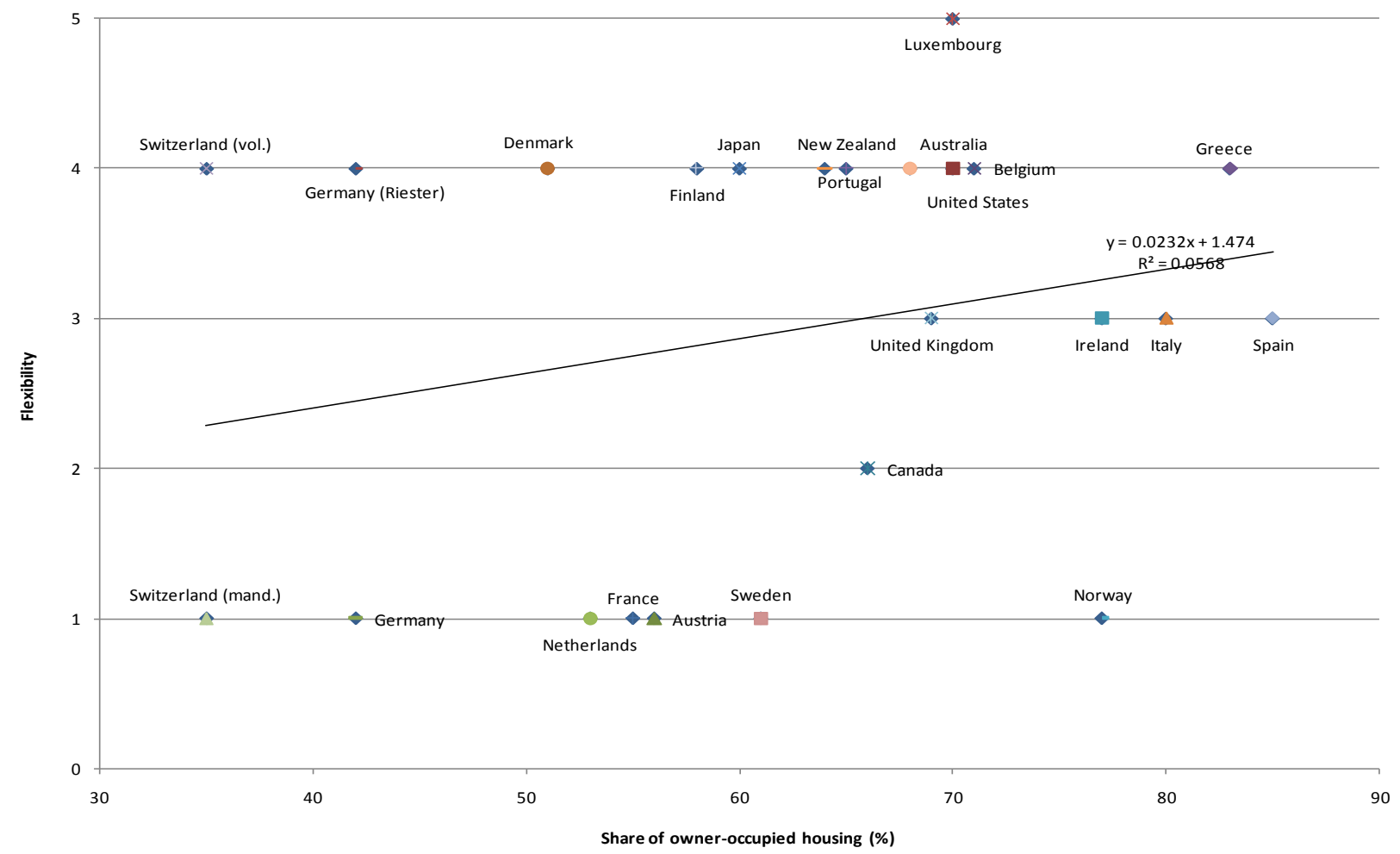

Source: The share of owner-occupied housing comes from Catte et al. (2004). The information to construct the index on flexibility comes from Antolin et al. (2008). It assumes a value of 1 to 5 depending on whether the payout options allowed are just life annuities; life annuity or programmed withdrawals; lump-sum plus life annuity, lump-sum or life annuity; or lumps-sum, respectively.

\footnotetext{
${ }^{8}$ Reverse mortgages are financial instruments that may allow people to get periodic payments during retirement using their house as a collateral. Providers of reverse mortgages will keep the house at death of the retiree.
} 


\section{d. Other Factors}

Allowing greater choice and more flexibility in retirement payout options may also depend on other government priorities and policies. For example, if governments have deliberately introduced individualaccount type systems (particularly those involving individual choice) in order to foster a greater sense of personal responsibility and ownership of pension assets amongst the population, consistency may require them to also allow flexibility and choice when it comes to retirement products. Individuals may rightly be annoyed if after saving for 30+ years in what they are told are their "own" accounts, the government subsequently requires them to buy a particular, regulated product at a specified time. If pension assets have to be placed in a limited range of guaranteed products during the accumulation phase, however, it would seem consistent with government objectives of high levels of protection to require individuals to purchase similarly restrictive forms of retirement income. For example, it makes sense in a country where participation in DC personal accounts is compulsory during the accumulation phase (e.g. Chile) to restrict the use of payout options and to guarantee a certain level of annuitization. But countries with more liberal rules in the accumulation phase (e.g. Australia, United Kingdom) may also need to have more choice in the payout phase.

In addition, governments heavily focused on financial education may wish to allow more flexible forms of retirement payouts, such as lump-sum and programmed withdrawals, or indeed a full range of choices. One of the main arguments for restricting retirement payout options is the lack of financial literacy among retirees, which challenges the ability to manage lump sums and programmed withdrawals effectively. However, if governments have active policies for improving financial literacy - including improving individuals' understanding of the risks involved in the payout phase and different retirement payout options - they may consider allowing more flexibility and choice of retirement products. Surveys have suggested that there are direct links between income level and financial education. Therefore governments in higher income countries may consider their populations to have a greater financial understanding and therefore, to allow greater choice in retirement products. Yet, upon further investigation, no explicit link between GDP per head and flexibility of retirement products was found. ${ }^{9}$

The main conclusion from this section is that countries may need to reconsider the way their payout phase is structured. Countries with a relative higher degree of annuitization of retirement income from PAYG-financed plans, DB plans or the higher other sources of wealth available to finance retirement fail in allowing more flexible choice among retirement options. However, different categories of people according to absolute income and replacement rates should be considered, making a one policy-fits-all inappropriate. This section has highlighted the trade-off between flexibility and protection from longevity risk when deciding the degree of choice among retirement payout option that a country should consider. In this context, countries where much of individuals' retirement income comes from assets accumulated in the DC pensions may need to annuitize a large amount of those assets. In the case of countries where participation in DC pensions is mandatory, policy makers may consider mandating a certain level of annuitization or, at least, mandate annuitization at old ages (e.g. age 85). Policy makers may also wish to consider allowing the flexibility to combine different type of pay-out products in order to achieve an optimal balance between the flexibility and protection trade-off. For example, using deferred life annuities bought at the time of retirement combined with programmed withdrawals allow for both flexibility (thanks to programmed withdrawals) and longevity protection (thanks to the deferred annuity).

\footnotetext{
${ }^{9}$ The reader is cautioned that the lack of explicit correlation could be due to using an average measure (GDP per head) as an approximation to survey results suggesting that it is the individual level of income that it is positively correlated with financial education.
} 


\section{II.3. How does the market context affect the choice of retirement payout options?}

Aside from the theoretical arguments for or against allowing a certain range of retirement payout options, policy makers may also face practical restrictions. Indeed, countries may lack well developed insurance markets able to provide life annuity products. Moreover, annuity markets are fraught with problems. For example, countries with mature annuity markets (e.g. United Kingdom) report several constraints to further expansion of annuity markets (Rusconi, 2008). Moreover, countries where annuity markets are in their infancy, may wonder whether it is possible to develop an annuity market at all. Therefore, this section examines the question policy makers face as to whether annuitization can be allowed or even encouraged where the market for annuity products is limited at present or indeed does not exist at all. ${ }^{10}$

\section{a. The level of development of insurance markets}

Countries that lack or have less well developed insurance markets may wish to allow lump-sums or programmed withdrawals instead of life annuities, as these products may not be readily available. ${ }^{11}$ In this context, more flexible payout options are the result, not of a conscious policy to allow more flexibility, but of a lack of sophisticated insurance markets. Correlation results linking insurance market penetration and the degree of flexibility of the payout phase slightly suggest that countries with more penetration of insurance markets (measured as gross direct insurance premiums as a share of GDP) show a lower degree of flexibility in the payout options, failing to confirm that offering life annuities may be the result of having more sophisticated insurance markets (Figure 4). However, again, these results are not robust statistically and are vey sensitive to specific data points. ${ }^{12,13}$

\footnotetext{
${ }^{10}$ Rusconi (2008) provides a detailed discussion of the annuity markets around the world.

${ }^{11}$ Section V below discusses the possibility of having annuity providers different than (life) insurance companies.

${ }^{12}$ For example, eliminating the Slovak Republic makes the correlation slightly positive. Adding the Swiss voluntary private component makes the relationship completely flat.

${ }^{13}$ Results are similar when using life insurance density (gross life insurance premiums as a share of the population).
} 
Figure 4. Relationship between penetration of life insurance markets and flexibility of retirement payout options

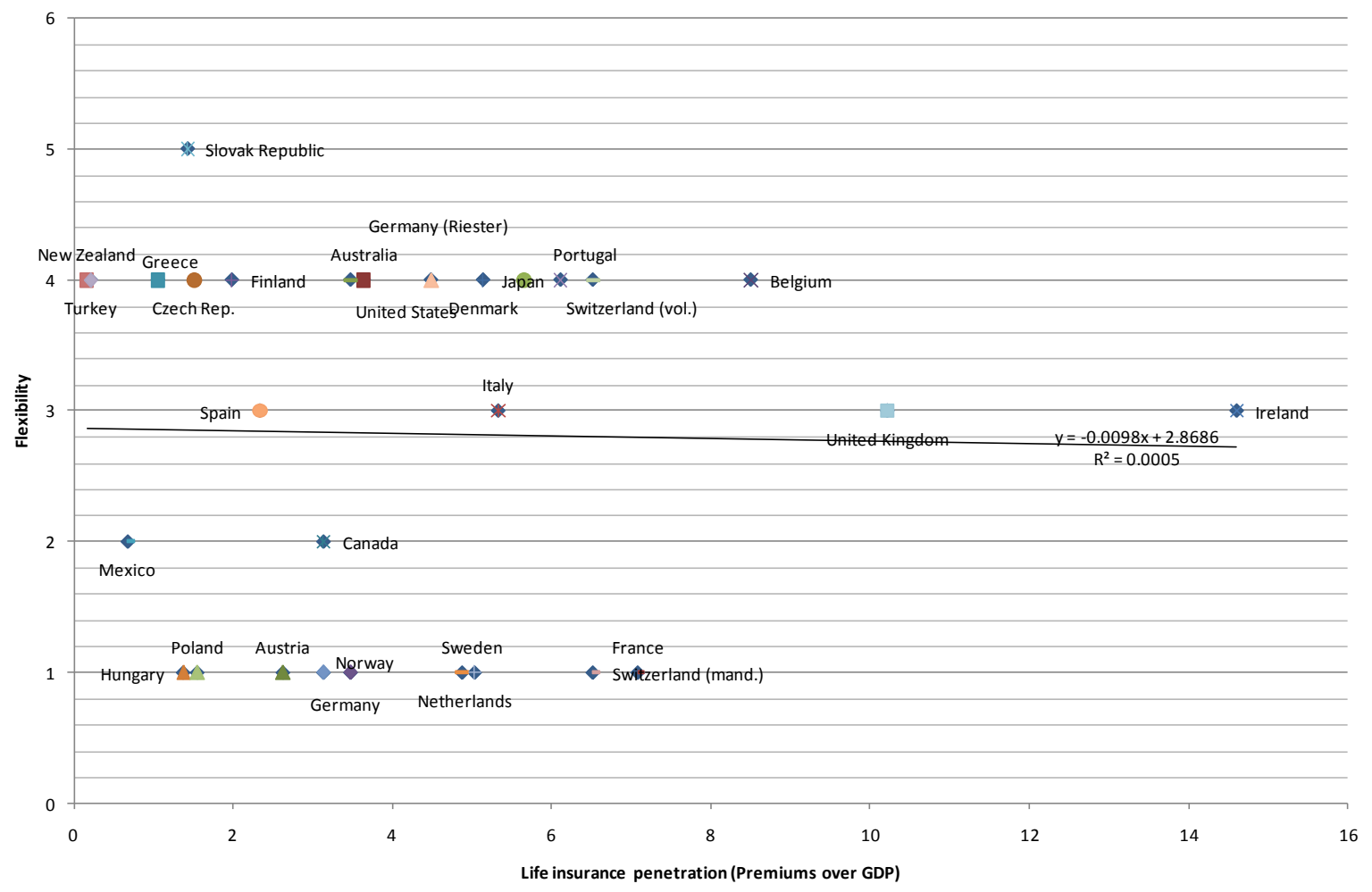

Source: Data on penetration comes from the OECD Insurance Statistics and it refers to gross life premiums as a share of GDP. The information to construct the index on flexibility comes from Antolin et al. (2008). It assumes a value of 1 to 5 depending on whether the payout options allowed are just life annuities; life annuity or programmed withdrawals; lump-sum plus life annuity, lump-sum or life annuity; or lumps-sum, respectively.

However, policy makers who wish to introduce annuities into their list of pay-out phase options should not necessarily be put off by the lack of an annuity market. The experience of Chile shows that mandatory annuitization and the development of an annuity market can go hand-in-hand. Rocha and Thorburn (2008) conclude that one of the most important lessons that can be extracted from the Chilean experience is the feasibility of developing a market for retirement products when one did not exist in the first place. Chile applied a conservative approach coupled with strong regulation. This approach to product regulation may be appropriate for countries that expect assets accumulated in DC plans to play a major role in retirement provision. The Chilean experience shows the importance of developing long-term financial instruments in order to reduce annuity providers' exposure to risk; the need to make an early effort to produce appropriate mortality tables to be use for regulatory purposes; and the advantage of imposing strict capital regulations on providers to address investment and mortality risk

\section{b. What are the main constraints facing annuity markets?}

Annuity markets suffer from constraints that stem from demand and supply concerns (Box 1). On the demand side, these concerns include the level of annuitization from PAYG-financed pensions; the dichotomy between the request for straightforward annuity products and products that address as many annuitants' concerns as possible; as well as tax disadvantages from converting voluntary personal retirement savings into annuities (Brown, 2008; and Antolin et al., 2008). 
Pricing problems related to adverse selection, lack of competition among providers, and the demand for annuity products involving many guaranties, coupled with the problems annuity providers encounter to deal with longevity risks are the main supply challenges facing policy makers to promote annuitization, and encourage further expansion of annuity markets.

\section{Box 1. Demand and supply limitations to annuity markets ${ }^{14}$}

This box highlights the main constraints in annuity markets. There are supply and demand factors deterring further development of annuity markets.

Demand side limitations to annuity markets include:

- Crowding out by social security provision

- Crowding out by other forms of pension saving such as defined benefit occupational pensions

- Perception of unfair pricing

- The motive to bequest assets on death to dependents

- Personal circumstances, such as family support, the need to cover the costs of medical care, insufficient assets to contemplate purchasing an annuity etc.

- Competing more flexible alternative product forms at retirement, such as programmed withdrawals

- Tax disadvantages (or tax-favoured competing assets)

- Mistrust of institutions providing annuities

Supply side limitations to annuity markets include:

- High prices: Adverse selection

- Incomplete markets: lack of inflation protection, lack of equity market exposure, and illiquidity and the need to insure against multiple shocks

- $\quad$ Exposure to the uncertainty surrounding future mortality and life expectancy outcomes, i.e. longevity risk.

- Lack of financial instruments to hedge against longevity risk

- Appropriate asset types are available in insufficient quantity

- Concerns with regulatory capital requirements or with the strength of existing providers that would make it difficult for new entrants to survive

- The margins for providers are not very attractive

- Intermediation: intermediaries selling and providing advice on annuity products lack basic understanding of the products they sell.

c. How to encourage and promote annuity markets?

Many policy options exist to encourage and promote annuity markets, from mandating annuitization to improving financial education and dealing with longevity risk. ${ }^{14}$ Mandatory annuitization is the ultimate way to create demand and promote annuity markets, and may well help with most of the pricing problems stemming from adverse selection. Adverse selection is one of the main reasons for (perceived) high annuity prices (Finkelstein and Poterba, 2002, 2004; Rusconi (2008); Stewart, 2007). Adverse selection is the result of asymmetric information about the annuitant's life expectancy and/or health, which is perhaps known to the annuitant but most likely unknown to the annuity provider. As a result, unless annuity

\footnotetext{
${ }^{14}$ For details and a more complete discussion see Stewart (2007) and Rusconi (2008).
} 
purchases are mandatory, individuals with better-than-average life expectancy are more likely than others to buy an annuity. This higher share of high-life-expectancy individuals inclines annuity providers to charge higher annuity prices, which further discourage individuals with lower-than-average life expectancy from participating, and thus only exacerbates the problem. Consequently, equilibrium would be reached only at prices higher than in the case of full information. The only way to break this spiral of higher annuity prices resulting from adverse selection is to make annuitization mandatory for all individuals. However, mandating annuitization may not fit well in pension systems were individuals are allowed choice during the accumulation phase. Additionally, in countries where a large share of retirement income is already annuitized through PAYG-financed pension, mandating annuitization restricts choice and options without really improving the situation.

However, countries may opt for less severe approaches to promote annuitization such as softcompulsion, tax incentives, better information disclosure, and improving financial awareness and financial literacy.

Soft-compulsion, for example, automatic annuitization as a default option with an opt-out clause, takes into account the importance of inertia and passive decision making highlighted by studies of behavioural economics. However, even when people opt out, some minimum annuitization requirements may still need to be in place to protect people from longevity risk at very old ages, and avoid having people fall into social protection at late ages. Using tax incentives to promote earmarked retirement savings ${ }^{15}$ or providing better information and improving financial awareness and financial literacy could also increase annuitization.

Countries looking at promoting annuitization through tax incentives need to proceed with care, as incentives depend on the way tax breaks are designed and the income level of the individual. Tax deductions provide incentives that increase with income, while tax credits provide higher incentives for low income individuals (Antolin and Lopez, 2008). If low income individuals are highly annuitized through PAYG-financed pensions then tax deductions may be more appropriated. ${ }^{16}$ However, when the purpose of tax incentives is to promote retirement savings from low income individuals, tax credits will be more appropriate. ${ }^{17}$

Despite measures to promote annuitization, some people may lack longevity protection in particular at very old ages (e.g. 80 or older), and consequently risk falling into poverty or into the State safety net. In order to avoid this outcome, countries may consider some sort of mandated annuitization for very old ages. For example, to mandate buying at retirement (or during the accumulation phase) a deferred annuity that starts paying out at very old ages would protect everyone from longevity risk at very old ages.

Looking at other supply side constraints, the most urgent constraint policy makers made need to tackle is the lack of longevity hedging products. Annuitization protects individuals from longevity risk, but longevity risk does not go away; instead, annuity providers bear the risk. Dealing with longevity risk is one of the main arguments explaining why life insurance companies are not interested in entering or fully participating in annuity markets. Their reluctance to participate, in turn, may reduce competition in annuity markets. Life annuity providers need to forecast longevity risk, include it in their pricing policies, and then

\footnotetext{
${ }^{15}$ However, it should be noted that tax incentives may not increase saving but shift savings from other vehicles into retirement (Antolin and Lopez, 2008).

${ }^{16}$ The level of replacement rates from PAYG-financed pensions for people earning half of average income are much higher than those in figure 1, while the replacement rates for people earning twice the average income have replacement rates from PAYG-financed pensions much lower.

${ }^{17}$ In countries where participation in pension plans is voluntary, low income individuals are less likely to participate than high income individuals (Antolin, 2008).
} 
transfer the risk to institutions better placed to deal with it. Unfortunately, there is a lack of financial instruments to hedge against this longevity risk, thereby complicating risk management and hindering the further expansion of the annuity markets.

In order to deal with longevity risk and thus promote competition in life annuity markets, governments could play a crucial role (Antolin, 2007; Antolin and Bloomestein, 2007) by producing, through their national statistical offices; a longevity index developed using a stochastic approach. Governments could encourage or support the development of a private market in longevity hedging products by producing a reliable and widely accepted longevity index to be used as a benchmark for pricing hedging products. ${ }^{18}$

\section{Who should provide annuities?}

Another important consideration for policy makers when attempting to develop or promote annuity markets is which entities should provide these products? There is a balance to strike between competition and safety of retirement savings when deciding who the providers should be. In general, countries may wish to allow many providers in order to promote competition, which leads to lower prices and costs. However, in order to protect retirement savings from bankruptcies of providers, a sound prudential framework needs to be in place.

\section{a. Insurance companies}

In practical terms, (life) insurance companies are likely to be the best prepared institutions to provide annuities. They are subject to capital adequacy requirements and to regulatory oversight to guarantee their safety and soundness. Additionally, they may be able to derive economies of scale from their overall life insurance business, and they have the experience and the expertise from their strong internal actuarial and administrative skills. Moreover, life insurance companies also have the advantage of working on the two sides of the markets as sellers of life insurance (mortality) and life annuities (life expectancy). As a result, they can offset both effects, achieving an almost perfect hedge: changes in mortality rates are bad news for one line of business, but good for the other.

However, life insurance companies show little interest in participating in the market for annuities in many countries. ${ }^{19}$ Indeed, the number of insurance companies selling annuities has fallen dramatically in recent years, notably in mature and developed annuity markets (Rusconi, 2008). The business of life annuities can be unprofitable as a result of low investment returns, increasing longevity risk, and high reserving requirements. Life insurance companies face high solvency requirements and are required to use mortality tables that may be too conservative and do not account for future improvements in life expectancy (Antolin, 2007). In countries where annuity markets are not yet well developed, the disincentives for insurance companies are more basic, ranging from a lack of accurate mortality tables for realistic pricing to more general issues of financial stability.

The limited number of insurance companies participating in the market for life annuities, combined with the fact that in some countries insurance companies are involved in both the accumulation phase and the payout phase, which may restrict choice, could affect competition, fees and costs. Approaches to deal with this competition problem include improving information disclosure from participating insurance companies; or, instead, policy makers could consider alternative providers to life insurance companies.

\footnotetext{
${ }^{18}$ Antolin and Blommestein (2007) argue that governments are not well placed to issue longevity-index bonds as some commentators has suggested as they themselves are already exposed to significant longevity risk from their public pension systems.
}

${ }^{19}$ See Antolin et al. (2008). 


\section{b. How to disseminate information as regards annuity providers?}

One concern as regards choosing a suitable annuity provider is the lack of appropriate information available to retirees and their lack of expertise. The latter would require financial education programs (e.g. Brown, 2008), while the former could be undertaken by third-party arrangements that can assist the process of information dissemination. This dissemination could be achieved through an electronic quotation system (e.g. Chile's SCOMP), or through third-party private-sector arrangements such us financial independent advisors, brokers and actuarial consulting firms (IOPS, 2008).

Electronic quotation systems can help in collecting comparative information and prices and introducing some competition in annuity markets (with spreads and costs declining in the case of Chile see IOPS (2008)). The advantages of such schemes are that they help to smooth time of purchase risk, increase competition among providers, and provide a reliable source of information and directly comparable prices. Unfortunately, prospective annuitants may still require advanced financial knowledge and expert advice to choose appropriately. The authorities managing the UK's Open Market Option are therefore building a central portal for system and advise to backup central available pricing information (see IOPS, 2008).

Additionally, financial advisors could help prospective annuitants make appropriate choices. However, they may be costly and, moreover, the experience with these arrangements in some countries (e.g. USA, UK) is not very encouraging.

\section{c. What alternatives to life insurance companies exist?}

Given the problems with competition stemming from the reduced number of insurance companies participating in annuity markets, countries could consider alternative providers to life insurance. Such alternative providers include pension funds, separate financial institutions, and state annuity funds. Pension funds could retain the life annuity obligation providing an opportunity to earn profits by generating investment returns higher than those assumed by insurance companies in their pricing structures. However, this approach is fraught with complications. Pension funds are not subject to the same capital adequacy requirements as insurance companies, they may not have the skills and expertise needed, and are exposed to investment and longevity risks that have weighed down DB pensions plans. Evidence on pension funds retaining the life annuity obligation is mostly limited to DB plans (Antolin et al. 2008). Only in Australia, Denmark and Poland do DC plans keep the life annuity obligation (Denmark consequently regulating these plans as life insurance companies). Countries where annuity markets are far from developed could consider allowing pension fund to retain the life annuity obligation and regulate them as insurance companies or apply similar solvency requirements to protect individuals from provider insolvency. Guarantee schemes, (along the lines of DB pension protection funds or insurance protection funds which exist in several OECD countries), provide additional protection and may also be considered. However, if such solvency requirements are seen as too prohibitive and prevent providers from entering the annuity market, members and beneficiaries may have to bear some risks collectively. For example, a related approach would be for the pension fund to take the form of a not-for-profit mutual association (e.g. TIAA-CREF, Hungary), where participants collectively bear the longevity risk.

Life insurance companies or equivalent financial institutions exclusively focusing on underwriting retirement life annuities are another solution. However, these entities would lack the broad based business of a traditional insurance company and the advantage of working on both sides of the market, thereby offsetting the impact of mortality and life expectancy.

Consequently, an alternative that it is attracting a lot of interest is to have a single entity or state annuity fund. A central provider would reduce costs through economies of scale and pooling of risks. 
Moreover, it would be a 'not for profit' provider and, as opposed to private providers, it may not suffer from the risks of insolvency and bankruptcy. Additionally, it may not be subject to requirements for solvency margins. Besides, a State annuity fund would guarantee a certainty of supply. Countries where DC plans substitute PAYG-financed pensions and have incipient annuity markets may consider this route as a temporary route until the annuity market develops, keeping in mind some of its downsides.

A central or state annuity fund may also suffer some important drawbacks. A state annuity fund would make taxpayers the ultimate guarantors of its solvency, and, moreover, governments would be taking on board investment and longevity risk, the latter on top of that already on their balance sheets from the PAYG-financed pensions. There is also the political risk to consider, as a state annuity fund may find it more difficult to dismiss political pressure. Additionally, questions arise on whether this central provider should be the sole provider or should openly compete with insurance companies in certain segments or in the overall annuity market. Insurance companies may find it more difficult to compete on a like-for-like basis with a central provider. Given the reported low level of profitability of existing annuity business, annuity providers may just withdraw from any segment of the annuity market where they may be in direct competition with the state annuity fund.

The final approach taken with respect to providers depends on the country context and the resulting balance between safety and competition. For countries with developed annuity markets, the more practical approach may be to address some of the problems leading insurance companies to withdraw or refrain from entering the market for life annuities. In this context, the approaches discussed above for dealing with longevity risk could help. Mandates to provide life annuities will also help. Countries with incipient annuity markets could begin by allowing pension funds to retain life annuity obligations and encouraging insurance companies to participate. They may also consider a temporary state annuity fund while the annuity market develops. Policy makers who wish to introduce annuities into their list of pay-out phase options should not necessarily be put off by the lack of an annuity market. The experience of Chile shows that mandatory annuitization and the development of an annuity market can go hand-in-hand (Rocha and Thorburn, 2008).

\section{What type of annuity products should be allowed?}

Aside from pay-out options that are allowed by pension regulation, pension authorities should also specifically consider the range of annuities products that are allowed. Again, consistency with the overall pension system and the regulators' goals need to be considered.

The type of annuity products that should be allowed is shaped by the trade-off between choice, risks and costs. As the previous section highlights, countries with a large share of retirement income annuitized from PAYG-financed pensions have more room to widen the choice of retirement payout options, including widening the range of annuity products available. Different annuity products offer different levels of guarantees and, thus, of risks; hence, in situations where a stable retirement income is already provided by the public PAYG pension, it may be appropriate to allow individuals to purchase annuity products that entail greater risks. For example, variable annuities would permit individuals to have access to stock market gains at the expense of assuming investment risk.

However, pension regulation may also need to consider another trade-off, the one between protection and cost. The greater the guarantees annuity products provide, the lower is the risk born by individuals, but the higher is the cost of such products. Policy makers therefore need to consider carefully that allowing individuals only to purchase highly secure, guaranteed annuities, costs will increase, reducing retirement incomes will be lower. 
Consequently, this section discusses the different types of annuity products available in light of the types of guarantees and risks they involve as well as the associated costs.

\section{IV.1. What types of annuity products are available?}

The type of annuity products available can be classified according to several dimensions in a nonhierarchical manner depending of the type of guarantees they provide (Box 2). The first dimension to classify annuity products is according to the duration of the payout commitment. First, there are fixedterm, annuity-certain or term-certain annuities that provide a retirement payout for a fixed period of time. These annuity products are a specific type of programmed withdrawals. Secondly, there are life annuities that guarantee retirement payments for the remaining life of the annuitant.

\section{Box 2. Classifying different type of annuity products}

There are several independent dimensions to classify annuity products (Figure 2.1). Annuity products can be classified according to how they are financed. In this context, there are single-premium annuities, those funded by a single payment or lump-sum, and flexible-premium annuities, those intended to be funded by a series of periodic payments or contributions. The series of payments under flexible-premium annuities can be fixed or variable, depending on whether the periodic contributions are a fixed or a variable amount. Annuity products can also be classified according to their primary purpose (i.e. accumulated assets or getting an immediate payment) into deferred and immediate annuities, as some annuity products are designed to facilitate accumulating resources over a certain period and thus defer the annuity payment(s), while other annuity products are designed for immediate pay-out. Flexible-premium annuities are only deferred.

Figure 2.1 Type of annuity products
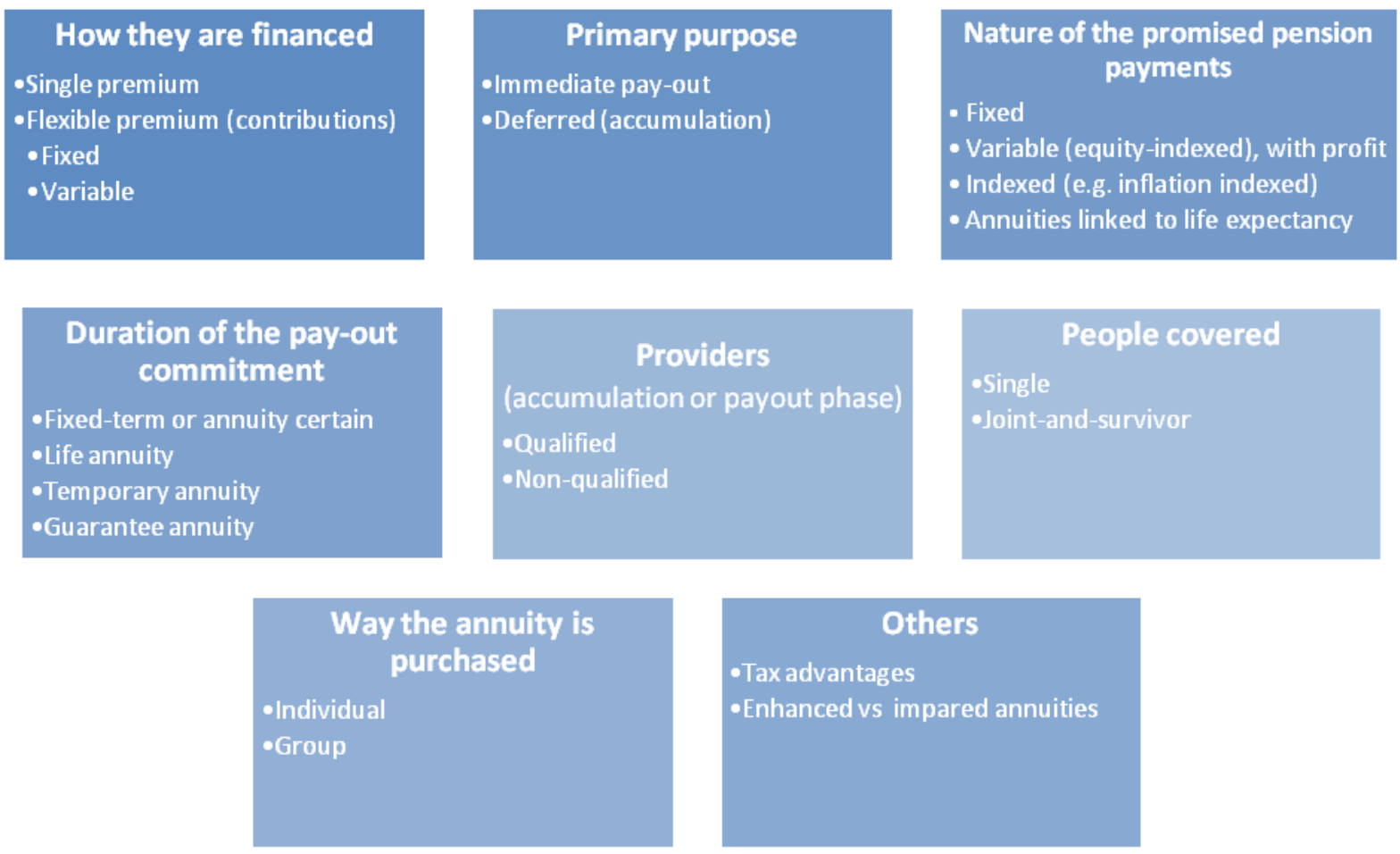

There are fixed, indexed and variable annuities depending on the nature of the promised pension payment. Fixed annuities are more conservative, while variable annuities are financially more aggressive. A fixed annuity guarantees a fixed and unchanging amount of pension. Indexed annuities come in various forms, but basically involve paying a 
pension that increases each year in some prescribed manner. The annual increase could be a fixed percentage, full or partial price inflation, dependent on the insurance company's profits, or it could be determined in some other manner. A variable annuity is one where annuity payments vary either in line with an equity index or other investment index or with the performance of the underlying assets. They provide the opportunity of continuing to participate in stock market returns, even after the annuity payments have started. There is now a new generation of annuities that adjust future annuity payments to reflect evolving changes in average life expectancy of the annuitants and their age cohorts.

Annuity products, depending on the duration of the pay-out commitment can be split into life annuities, which pay a stream of income for the entire life of the annuitant, fixed-term or certain annuities, which pay a stream of income for a fixed amount of time, temporary annuities that pay a stream of income for the earlier of the two, and guarantee annuities that pay for the latter of the two. The duration of the pay-outs is the more important feature in connection with longevity risk.

Annuity products can be further distinguished according to the type of provider into those where the provider during the accumulation and pay-out phases is the same (e.g. annuities as vehicles attached to certain retirement plans, such as $401(\mathrm{k}) \mathrm{s}$ or IRAs in the United States) and those where the provider in the pay-out phase is different.

Furthermore, depending on the number of people covered there are single life annuities and joint-and-survivor annuities and, depending on the way the annuity product is purchased there are individual or group annuities. There are other features that further distinguish annuity products, for example, whether the annuity product qualifies for tax advantages. Generally, most tax-favoured annuity products provide tax deductions for the contributions, tax-shelter the investment income, and then wholly tax the annuity payments. Additionally, new annuity products address the problem of shorter life expectancy of people with impaired lives: enhanced and impaired annuities.

Life annuities protect the annuitant from running out of resources at retirement, longevity risk, and from investment risk, but fail to address other concerns, and are consequently perceived as inflexible or restrictive. For example, in its simple form a life annuity does not protect a retiree's spouse or partner, does not allow for the possibility of leaving a bequest or the possibility of having access to portfolio investment returns, and does not protect against inflation. Furthermore, in several countries life annuities are designed only for the payout phase.

There are more complex life annuity products that address some of those concerns by providing additional guarantees. In this regard, joint-and survivor life annuities may cover more people than single life annuities; some life annuity products permit the leaving of bequests, whilst guarantee joint-life annuities provide a stream of income for the annuitant and the joint-insured late in life or for a fixed-term. Additionally, variable annuities, whether linked to an equity index or to a portfolio, permit the annuitant to have access to stock market returns even after retirement, though at the cost of partially eliminating protection from investment risk. Whilst fixed, life annuities provide a constant stream of income at retirement that falls in real terms as the annuitant ages, indexed life annuities provide a stream of income that will increase in line with an index of price inflation. 
Table 2. Annuity products, risks and guarantees

\begin{tabular}{|c|c|c|c|c|c|c|c|}
\hline & $\begin{array}{c}\text { Investment } \\
\text { risk }\end{array}$ & $\begin{array}{c}\text { Longevity } \\
\text { risk }\end{array}$ & $\begin{array}{c}\text { Inflation } \\
\text { risk }\end{array}$ & $\begin{array}{l}\text { Interest } \\
\text { rate risk }\end{array}$ & $\begin{array}{l}\text { Partner's } \\
\text { protection }\end{array}$ & $\begin{array}{c}\text { Provision } \\
\text { of bequest }\end{array}$ & $\begin{array}{c}\text { Facilitates } \\
\text { accumulation }\end{array}$ \\
\hline $\begin{array}{l}\text { Programmed withdrawals, term } \\
\text { annuity or annuity certain }\end{array}$ & No & No & No & No & Yes & Yes & No \\
\hline $\begin{array}{l}\text { Life annuity (single, fixed, } \\
\text { nominal, immediate) }\end{array}$ & Yes & Yes & No & No & No & No & No \\
\hline Joint and survivor life annuities & Yes & Yes & No & No & Yes & No & No \\
\hline Guarantee life annuities & Yes & Yes & No & No & No & Maybe & No \\
\hline Life join annuities with bequest & Yes & Yes & No & No & Yes & Yes & No \\
\hline Variable annuity & No & Yes & No & No & No & No & No \\
\hline Fixed indexed life annuity & Yes & Yes & Yes & No & No & No & No \\
\hline Deferred life annuity & Yes & Yes & No & No & No & No & Yes \\
\hline $\begin{array}{l}\text { Deferred joint indexed life } \\
\text { annuity with bequest }\end{array}$ & Yes & Yes & Yes & No & Yes & Yes & Yes \\
\hline
\end{tabular}

Source: OECD.

The cost of annuity products may increase directly with the amount of protection and guarantees they provide. It is important to highlight that the more guarantees annuity products contain the higher the cost may be, unless some other guarantees are reduced in exchange. In other words, flexibility and guarantees come at a price. In this context, a deferred, joint, index, life annuity with a bequest clause may provide the most guarantees but it may be also the most costly. Meanwhile variable annuities - by shifting the investment risk from the annuity provider to the annuitant - should be available at lower prices. Again regulation restricting the availability of annuity products should be consistent with the overall pension system. For example, in countries where an adequate pension is publically provided and individual choice and responsibility are encouraged, policy makers and regulators could be expected to allow retirees to purchase the type of annuity they wish - i.e. to balance the level of flexibility, protection and costs themselves. Yet in systems where individuals are highly dependent on their DC accounts to provide a stable source of income in retirement and regulations have protected their assets during the accumulation phase, regulation restricting choice to more guaranteed, protective annuity products (covering longevity, investment and inflation risks) may make more sense.

\section{IV.2. How to protect against the risk associated with buying an annuity?}

One of the main risks associated with buying an annuity is that associated with the timing of annuitization. Participants in traditional DC pension arrangements that decide to buy an annuity when reaching retirement liquidate their accumulated assets and immediately purchase a life annuity with them. As a result of this point-in-time sale of assets and point-in-time purchase of an annuity, they are exposed to a substantial risk that can curtail their pension payments significantly. Indeed, there is a large amount of luck involved in having a retirement date that coincides with favourable investment market conditions and favourable annuity purchase rates. Two people with identical careers and identical pension plan contributions can retire with amounts of lifetime retirement pensions that are substantially different, simply because their retirement dates were separated by a relatively short period of time

This risk associated with the timing of the purchase comes in two parts: the movement of the market up until the date of purchase and the level of interest rates - and therefore annuity rates - at the moment of purchase. People retiring face the risk of unexpectedly low asset values at the time their savings must be annuitized. If the stock market fell just before retirement, those retirees would have less wealth and their life annuity would be smaller than they had expected. Moreover, annuity rates may also be particularly low 
at the point of retirement (if interest rates are low and/or longevity increases have been factored in), again forcing an individual to lock-in a low level of retirement income. The unpredictability of the income that a given annuity premium can buy is certainly an issue. Even if an individual account holder can quite accurately predict the balance in their account at retirement age, they will not be able to predict the ratio of income to premium accurately until very close to the date that the annuity is locked in.

\section{a. Which approaches exist for facing the risk associated with the time of annuitization?}

Protection against this risk can take several forms. For example, using a gradual transition of assets from equities into matching assets in preparation for the annuity transition; ${ }^{20}$ protecting participant directly from this risk, taking steps to guide participants through the process in a way that at least manages the potential financial loss; or having rules allowing for flexible timing of annuitization.

Some countries directly protect participants by mandating minimum returns in the accumulation phase and specifying a conversion rate at retirement (e.g. Switzerland). ${ }^{21}$ Other countries (e.g. Chile) guide participants with default investment strategies that change with the increasing age of the participant to balance the need for exposure to high-volatility high-return equities in the early years and protected asset classes in the run-up to retirement. Some other systems have rules allowing a flexible timing of annuitization - i.e. people can annuitize their wealth over a certain period. For example, retirees could annuitize one-tenth of their retirement account each year between ages 65 and 75 . Because market prices vary less over a long horizon than over a shorter period, such a provision would reduce the volatility of retirement income. Deferring or providing flexibility in the annuity date at least allows individuals to benefit from an increase in the interest rates in the years immediately following the date when they would normally annuitize. However, such a policy does not guarantee any given rate of retirement income.

Yet if the entire retirement account must be annuitized within a certain time frame, the risk of switching investment portfolios cannot be eliminated. In the United Kingdom, for example, an annuity must be purchased with the entire account balance sometime before age 75 . Thus UK retirees face a decision similar to that of an investment manager: they must bet whether the market will go up or down in the future, a task at which many professionals fail. Variable-rate annuities (see below) would accomplish

20 The appropriate matching assets depend on the strategy on and around the date of the annuity purchase. Conventional bonds are the best vehicle to protect against the annuity rates applied to level annuities. Index-linked bonds are appropriate to hedge the risk involved in purchasing annuities that increase at the rate of inflation. Money market assets are the most appropriate for that portion of the accumulated assets that are to be taken in the form of cash. The situation is a little more complex if part or all of the assets are to be invested in a programmed withdrawal vehicle, but generally speaking, the best assets immediately before the transition are those that are to be utilized immediately afterwards.

${ }^{21}$ No country other than Switzerland stipulates a minimum annuity conversion factor. This has been set at 7.2 percent since the introduction of the compulsory system in 1985 . There are currently proposals under discussion for a significant decrease in its level to reflect the fall in interest rates and the increase in longevity. The annuity conversion factor is used when workers retire and convert their accumulated balances into a life annuity. Although a minimum conversion factor stipulated in absolute terms may not be advisable as it may either expose annuity providers to a high reinvestment risk or it may set the conversion factor at too low a level, some regulation of annuity prices (as well as products) the result would not be much different from pension funds offering constrained choice of indexed funds. For instance, a pension fund may publicize an investment policy that allocates 60 percent of assets in a broad equity index and 40 percent in a broad bond index. If it were to deviate from this policy and allocate 80 percent in equities and this resulted in a lower return than the publicized allocation it could be required to make up the shortfall in returns may be warranted. At the very least, there should be extensive publicity and analysis of the products and prices offered by different insurance companies. 
the same objective (i.e. minimize the exposure of the worker to risk stemming from interest rate fluctuations around the retirement date). ${ }^{22}$

Offering a substantial window of time for converting all savings into an annuity has a further disadvantage: it exacerbates adverse selection. Those who expect a shorter life span could postpone their annuitization and -- if they happen to die before annuitization -- could leave the remaining account balance to their estate. Such behavior would lead to a healthier-than-average pool of annuitants with longer-thanaverage life expectancy, defeating the purpose of the mandate.

Finally, consideration could be given to deferred annuity as products that could bridge the accumulation and payout phases, partly offsetting the risk associated with the timing of annuitization. Immediate life annuity products are designed to provide a stream of income immediately after paying the premium. They are appropriate products for the payout phase but are exposed to the risk associated to the timing of annuitization. However, deferred life annuities are designed to facilitate accumulating resources over a certain period of time and, thus, defer the annuity payments. Buying a deferred life annuity during the accumulation phase, enables one to link the accumulation and payout phases, which reduces the risk associated with the timing of annuitization.

Policies relating to protecting against timing risk again need to be aligned with the general pension system. Once more there is a trade-off between cost and protection. If the pension system does not require a great dependence on annuity income in retirement, then the rate at which individuals lock-in an annuity is less critical. However, if the pension system in structured so that individuals are highly reliant on the income generated by their accumulated pension assets, then locking in as high a rate as possible is very important- and these various ways of protecting against timing risk need to be considered carefully by policy makers.

\section{Summary and policy recommendations}

This paper has addressed some important policy questions related to the design of the payout phase for assets accumulated in DC pensions. For this purpose, it has presented a framework of thought to guide policymakers. The paper has highlighted the different tradeoffs that exist when designing the payout phase, and it has stressed the importance of the country context, in particular how the payout phase of DC pensions should fit into the general picture of the different sources of income available for retirement. The driving argument has been that policy makers need to consider carefully the choices allowed at retirement to ensure consistency with the goals of the pension system.

The first issue addressed was the choice among the main forms of retirement payout options available for allocating assets accumulated in DC plans. This decision is determined by the balance to be struck between flexibility and protection from longevity risk, and by the country context. Among the different payout options, life annuities protect against running out of resources at retirement (i.e. longevity risk) and from falling into poverty or into the government safety net. However, life annuities are illiquid, and consequently lack the flexibility to address contingencies that people may face at retirement (e.g. need to pay down debt, health care expenses). Given this trade-off between flexibility and protection from

\footnotetext{
${ }^{22}$ Despite the flexibility allowed in the UK, almost all individuals buy their annuities between age 60-69 (2.3 when they retire). Few use the flexibility provided by the 50-75 age limit, and only 5\% annuitize over the age of 70 (Treasury report on Annuities markets). Therefore, even though there are benefits to later annuitization (i.e. flexibility, annuity rates increase with age, opportunities to continue making contributions and allowing for further investment growth), they are poorly understood. It is also difficult to say when the ideal annuitization age is as it depends on other factors (such as other sources of income, life expectancy, attitudes to risk etc). If ages for first and last annuitization points are introduced, they should adjust over time with life expectancy.
} 
longevity risk, countries that provide a significant level of retirement income already annuitized from their PAYG-financed public pensions (in absolute as well as relative replacement rate terms) may be better off allowing more choice and flexibility by letting people allocate their accumulated assets in DC plans as they please - into lump-sums, programmed withdrawals, life annuities or any combination of the above. On the contrary, retirees in countries for which most of their retirement income comes from DC plans may need to annuitize a larger share of their accumulated assets. Finally, one (potentially economical) way to achieve this balance between flexibility and protection is to combine arrangements - such as a programmed withdrawal with a deferred life annuity bought at the time of retirement (the programme withdrawal providing some flexibility and liquidity to face any contingencies and the deferred annuity insuring against longevity risk at a cost of only a relatively small portion of the assets accumulated in DC plans).

A practical constraint that regulators face when considering life annuities is whether there is a well functioning annuity market. Therefore, the second issue addressed in the paper has been how to promote annuitization and deal with the problems facing annuity markets. Annuitization can be mandated, which directly eliminates most problems associated with adverse selection. However, some countries may prefer less severe approaches such as annuitization as the default option with an opt-out clause. Countries may also promote annuitization by introducing tax incentives and improving financial education. When using tax incentives care needs to be taken as regard their design and their relationship with income levels. Independently of the way annuitization is promoted, policy makers may need to make sure that all retirees are annuitized at very old ages in order to safeguard them from longevity risk or falling back on state pensions. In this context, the paper suggests allowing choice in allocating assets accumulated in DC pensions, but mandating retirees to buy a deferred life annuity that begins paying at very old ages (e.g. 80). Regarding the main problems facing annuity markets, most stem from adverse selection, lack of competition among providers, and difficulties of dealing with longevity risk, which affects pricing and costs. Adequate regulation is probably the best approach to deal with these problems and promote further expansion of annuity markets. However, it should be noted that the lack of a developed market need not prevent policy makers from requiring or encouraging annuitization - as the case of Chile shows.

The third issue addressed by the paper focused therefore on regulation, in particular, the factors determining which institutions should provide annuities and how to promote competition in annuity markets. In practical terms, life insurance companies are better prepared to offer life annuities as they have the technical capabilities, the expertise and, in theory, may be naturally hedged as they may operate in both sides of the market (life expectancy and mortality). However life insurance companies seem uninterested in participating in the market for life annuities, which has the effect of reducing competition and increasing costs. One of the main arguments to explain this lack of participation relates to the problems in dealing with longevity risk, in particular, the lack of financial instruments to hedge against longevity risk and the need to use well defined mortality tables, so that provision and capital put aside can be adequate. The paper examines possible alternative providers to insurance companies, such as pension funds (though care should be taken that they are subject to similar capital adequacy requirements as life insurance companies), separate financial institutions (though these may lack the broad-based business), and a single entity or state annuity fund. This latter alternative is attracting interest among policy makers (though the issue of how to combine a state annuity fund and life insurance companies competing in the same market may need to be considered further).

The paper also looked into the type of annuity products that should be allowed. This decision involves a trade-off between choice, risks and costs. A wide variety of annuity products exist, which are designed to address different annuitants' needs (e.g. bequest, access to stock market returns, inflation protection). However, the direct relationship between cost and the guarantees involved in these products needs to be considered by policy makers - as does the shifting of risk between providers and individuals these products may involve. Again, how much risk individuals can and should bear through their DC pensions depends on how large a part these pensions play in overall retirement incomes. Additionally, buying annuities is 
fraught with risks, in particular the risk associated with the time of purchasing. As discussed throughout the text, one product that seems to address many problems are deferred life annuities, which apart from insuring against longevity risk, partially address the time of purchasing risk. Moreover, buying the deferred life annuity at the time of joining a DC plan may help bridge the accumulation and the payout phases. Unfortunately, they do not seem to attract much interest from providers (as they expose providers to the full length of longevity risk) or consumers (financial education studies show that most individuals are unable to assess accurately the advantages of deferring payments). The negative impact on retirement savings of the risk of time of purchasing can also be ameliorated by an electronic quotation system and more a flexible timing of annuitization. As argued through out this paper, the larger the role played by DC pensions in the overall system, the more important it is for policy makers to address the amelioration of this timing risk.

The main policy recommendation stemming from the discussion is for policy makers to mandate deferred life annuities that start paying at very old ages (e.g. at age 85) and allow for the remaining assets accumulated in DC accounts to be allocated as programmed withdrawals (preferably with flexibility to face contingencies). ${ }^{23}$ With these arrangements policy makers accomplish a balance between flexibility and protection from longevity risk. Moreover, the cost of a deferred life annuity that starts paying at very old age is only around $10-15 \%$ of the assets accumulated at retirement. In addition, these arrangements, apart from eliminating the risk of outliving one own resources and falling into poverty, largely offset the timing risk.

Furthermore, mandating a deferred life annuity that starts paying at old age removes any worries about the type of annuity products to allow. People should be allowed to use their remaining balances to buy any type of annuity products if they wish, as protection from longevity risk is guarantee. Additionally, this may encourage further development of annuity markets and attract providers as well. In the context of providers, the discussion suggests that policy markers should allow any provider as long as they are sufficiently regulated and competition is guaranteed.

\footnotetext{
${ }^{23}$ Yet, people may be free to allocate them as they wish, as long as a minimum periodic payment schedule (e.g.
} minimum pension) is agreed for the period between retirement and age 85 . 


\section{REFERENCES}

Antolin, P. (2007) "Longevity Risk and Private Pensions", OECD Working Papers on Insurance and Private Pensions, No. 4.

Antolin, P. (2008) “Coverage in Funded Pension Plans", OECD Working Paper on Insurance and Private Pensions, No. 19.

Antolin, P. and H. Blommestein (2007), "Governments and Markets in Addressing Aggregate Longevity Risk", Forum Financier, Revenue Bancaire et Financier 2007/2

Antolin, P. and E. Lopez (2008), "Tax Incentives and Retirement Savings", forthcoming OECD Working Paper on Insurance and Private Pensions

Antolin, P., C. Pugh, and F. Stewart (2008), "Forms of benefit payment at retirement", OECD Working Paper on Insurance and Private Pensions, No. 26

Brown, J. (2008), "Financial education and annuities", paper prepared for the OECD project on financial education.

IOPS (2008), "Transparency and competition in the choice of pension products: The Chilean and UK experience" forthcoming IOPS working paper.

Finkelstein, A., and J. Poterba. 2002. "Selection Effects in the United Kingdom Individual Annuities Market." The Economic Journal 112(476): 28-50

Finkelstein, A., and J. Poterba. 2004. "Adverse Selection in Insurance Markets: Policyholder Evidence from the U.K. Annuity Market." Journal of Political Economy 112(1): 183-208

Catte, P., N. Girouard, R. Price and C. André (2004), Housing Markets, wealth and the business cycle, OECD Economic Department Working Paper Series, June 2004

OECD (2007), Pensions at a Glance, OECD Paris

OECD (2008b), Pension at a Glance: Asia Pacific, OECD Paris

Rocha, R., Thorburn, C., (2008), 'Developing Annuity Markets: The Experience of Chile, World Bank publication

Rusconi, R. (2008), "National annuity markets: features and implications", OECD Working Paper on Insurance and Private Pensions, No. 24

Stewart, F (2007) Policy Issues for Developing Annuities Markets, OECD Working Papers on Insurance and Private Pensions, No 2.

Whitehouse, E. (2007), Pensions Panorama, World Bank, Washington DC. 